Transportation Research Forum

Productivity, Pricing and Profitability in the U.S. Rail Freight Industry, 1995-2004

Author(s): Carl D. Martland

Source: Journal of the Transportation Research Forum, Vol. 45, No. 3 (Fall 2006), pp. 93-108

Published by: Transportation Research Forum

Stable URL: http://www.trforum.org/journal

The Transportation Research Forum, founded in 1958, is an independent, nonprofit organization of transportation professionals who conduct, use, and benefit from research. Its purpose is to provide an impartial meeting ground for carriers, shippers, government officials, consultants, university researchers, suppliers, and others seeking exchange of information and ideas related to both passenger and freight transportation. More information on the Transportation Research Forum can be found on the Web at www.trforum.org. 


\title{
Productivity, Pricing and Profitability in the U.S. Rail Freight Industry, 1995-2004
}

\begin{abstract}
by Carl D. Martland
Rail industry productivity grew by 7\% per year from 1984 to 1995, but most of the benefits to the industry were offset by reductions in rail rates and the increasing need for capital expenditures. Rail rates declined by more than one-third during that period, while financial measures, such as return on shareholders equity and net railway operating income, showed only a modest improvement. From 1995 to 2004, productivity improved 5\% per year, prices continued to fall, and financial performance was flat or declining. There is no doubt that productivity improvements helped railroads make very significant reductions in their costs during this 20-year period. However, by 2004, the long-term trends were coming to an end. The rate of productivity improvement was declining, rates were starting to rise, and capacity and service problems were becoming more serious. With higher rates, many of the Class I railroads were coming close to earning their cost of capital. The combination of increasing profitability, declining service, and inadequate capacity is unlikely to be sustainable. The lack of capacity and deteriorating service quality are seen as serious problems not only for rail customers, but for public agencies at the local, state, and federal levels. Railroads will need financial and planning assistance from these agencies as they seek to provide sufficient capacity to handle the potential growth in traffic that is expected over the next 20 years.
\end{abstract}

\section{INTRODUCTION}

This paper addresses historical trends concerning productivity, prices, and profitability in the U.S. rail industry during the period 1995 to 2004. Prior research documented the sources of the productivity improvements that were achieved by the railroads between 1965 and 1995 (Martland 1999). Both the beginning and the end of that period were reasonably good years for the rail industry. In between, the industry struggled through financial difficulties, responded to major regulatory changes, and rationalized its network and operations. Throughout that period, productivity improvements provided annual benefits on the order of $\$ 25$ billion per year by 1995, a year when actual operating expenses for the Class I railroads were just under $\$ 28$ billion. If railroad productivity had been the same as in 1965, operating expenses in 1995 would have exceeded \$53 billion. Had prices remained at 1965 levels (in constant dollar terms), rail industry profits would also have increased on the order of $\$ 25$ billion. In fact, prices fell significantly following deregulation of the rail industry in 1980, and rail profits were less than $\$ 4$ billion in 1995, or about the same in constant dollar terms as in the mid-1960s or the mid-1980s. Despite improvements that often exceeded 7\% per year in physical productivity, rail industry financial performance was essentially unchanged from the mid-1960s to the mid-1990s.

Martland (1999) predicted that the railroad industry was likely to encounter financial problems because the pressure on prices would be expected to continue, while the rate of productivity growth would decline. At the time, this was a contrarian view. The rail industry was then in relatively good financial shape, and various industry leaders and consultants lauded prospects for the future - so long as the industry was not re-regulated (e.g., Morrison and Winston 1999, Harper 1996, Gallamore 1998, and Rennicke 1998). Martland (1999), therefore, struck a rather discordant note with pessimistic conclusions regarding profitability and the industry's ability to deal with capacity, service quality, and other strategic problems.

Morrison and Winston (1999) presented a different view of the rail industry's history and its prospects for the future. From their perspective, deregulation had been the key to transforming the 
rail industry from a system that provided poor service to customers and stockholders to one that was able to "lower its costs and pass on these cost reductions in the form of lower prices and better service to customers." They identify computers, double-stack container trains, improved communications, and many other technological and operating innovations that directly led to higher productivity; but they argue that these advances were realized only because of the new incentives that deregulation gave to firms. Gallamore (1999, p. 495) espoused similar views, but he also called for research to figure out what actually happened: “A strong before-and-after case cries out for examination, as it is apparent that railroads foundered under the final decades of Interstate Commerce Commission (ICC) regulation and have recovered remarkably since regulation was relaxed in 1980.” He goes on to identify many of the technological and institutional changes that happened after deregulation, changes that he believed were in fact caused by or accelerated by deregulation.

The goal of this paper is to provide some insight into the extent and sources of productivity improvement in the rail industry since 1995, and to consider the extent to which productivity improvement has been translated into improved financial performance. This paper, therefore, provides some input relevant to Gallamore's call for a detailed before-and-after assessment of the impacts of deregulation.

This paper is primarily concerned with the period 1995-2004. During this period, major mergers transformed the national network, while burgeoning traffic challenged the capabilities of the system. Problems in consummating the mergers, difficulties in expanding capacity to keep pace with traffic growth, and severe weather resulted in extended periods of congestion, service complaints, and public outrage concerning rail performance. While the industry did manage substantial improvements in productivity, most of the benefits were once again passed on to rail customers in terms of lower rates. As a result, financial performance for the industry peaked around 1996, then stabilized at a lower level through 2004.

The paper presents two levels of analysis regarding productivity: one based upon aggregate measures and one based on a more detailed analysis of specific sources of productivity improvement. Both levels of analysis indicate improvements on the order of 50\% during the nine-year period. Productivity improvement of this magnitude is beneficial to society because fewer resources will be needed to move freight by rail. Substantial productivity improvement does not automatically result in improved financial performance for companies or an industry because prices are determined in the marketplace. For many years, declining prices for rail service offset the savings to the railroads from productivity improvements. As a result, financial performance was relatively stable. Only in 2004 did rail prices begin to rise, allowing better financial performance despite service problems and rising costs related to capacity constraints.

\section{TRENDS IN PRODUCTIVITY, PRICING, AND PROFITABILITY, 1995-2004}

In this research, output was measured in terms of its value to the customer. Each shipment was viewed as a different type of output, and total output was measured by weighting each shipment by the price that was paid. Over time, output can change because of a change in traffic volume, traffic mix, or price. An output index was created for each year by dividing freight revenue by a price index, a technique that has been used in other studies of railroad productivity (e.g., Waters 1997). For the period 1984 to 1999, it was possible to use the price index developed by the Surface Transportation Board (2000). This index compares prices for similar movements during different time periods, and it has been found to be the best of the available measures of rail price (Dennis 2005). For the period from 2000 to 2004, changes in prices were assumed to be proportional to the changes in the constant dollar revenue per ton-mile as reported by the Association of American Railroads. ${ }^{1}$

The first three rows of Table 1 show the absolute values for carloads, tons, and revenue tonmiles for the base year 1995 and for 2000 to 2004. The next three rows show the same information expressed as indices, with the base year equal to 100 . The last three rows show the key factors used 
to create a more general output index. Freight revenue is converted to output by dividing by the price index and comparing the results to the base year 1995.

Table 1: Class I Railroad Output, Various Measures, 1995-2004

\begin{tabular}{lcccccc}
\hline & $\mathbf{1 9 9 5}$ & $\mathbf{2 0 0 0}$ & $\mathbf{2 0 0 1}$ & $\mathbf{2 0 0 2}$ & $\mathbf{2 0 0 3}$ & $\mathbf{2 0 0 4}$ \\
\hline Carloads (million) & 23.7 & 27.8 & 27.2 & 27.9 & 28.7 & 30.1 \\
Tons (million) & 1549 & 1738 & 1742 & 1767 & 1779 & 1844 \\
Ton-Miles (billion) & 1306 & 1466 & 1495 & 1507 & 1551 & 1663 \\
Carloads (index) & 100 & 117 & 115 & 118 & 121 & 127 \\
Tons (index) & 100 & 112 & 113 & 114 & 116 & 119 \\
Ton-Miles (index) & 100 & 112 & 114 & 115 & 119 & 117 \\
Freight Revenue & $\$ 31.4$ & $\$ 33.1$ & $\$ 33.5$ & $\$ 34.1$ & $\$ 35.4$ & $\$ 39.1$ \\
(billion) & 100 & 86.9 & 84.3 & 83.7 & 82.9 & 83.3 \\
Price Index & 100 & 121 & 127 & 131 & 136 & 150 \\
Output Index & & & & & &
\end{tabular}

Data source: AAR, Railroad Facts, 2005.

The output index, which grew to 150 by 2004, increased more rapidly than the indices for carloads, tons, and ton-miles because it relates to prices rather than to physical measures. Some commodities with relatively high revenue per ton - especially shipments of intermodal containers and of automobiles - have been growing more rapidly than shipments of bulk traffic. The slight shift away from bulk traffic means that the industry is getting slightly more revenue from commodity groups where revenue per ton or ton-mile is either growing faster or declining less rapidly than for other commodity groups.

Total inputs include all freight expenses, i.e., all of the people, equipment, facilities, fuel, and supplies required to operate the system. The Railroad Cost Recovery Index (RCR), which has been produced by the Association of American Railroads for more than 50 years as a measure of inflation in the price levels of rail inputs, was used to restate rail operating expenses in terms of base year costs (Table 2). The operating expense was divided by the RCR, and the result was divided by the 1995 operating expense to get the input index. The index fell from 100 to 87.8 in 2002, then rose to 95.3 in 2004. Table 3 indicates strong productivity growth through 2004, as inputs declined despite substantial growth in output. The increase of 57\% from 1995 to 2004 is equivalent to an average increase of $5 \%$ per year compounded over this nine-year period.

Table 2: Railroad Inputs, 1995-2004

\begin{tabular}{lcccccc}
\hline & $\mathbf{1 9 9 5}$ & $\mathbf{2 0 0 0}$ & $\mathbf{2 0 0 1}$ & $\mathbf{2 0 0 2}$ & $\mathbf{2 0 0 3}$ & $\mathbf{2 0 0 4}$ \\
\hline Class I Railroads & & & & & & \\
Operating Expense (Billions) & $\$ 27.90$ & $\$ 29.04$ & $\$ 29.16$ & $\$ 29.59$ & $\$ 31.44$ & $\$ 35.11$ \\
Railroad Cost Recovery Index & 100 & 116.6 & 120.0 & 120.8 & 125.19 & 132.11 \\
Input Index & 100 & 89.2 & 87.1 & 87.8 & 90.0 & 95.3 \\
\hline
\end{tabular}

Data source: AAR, Railroad Facts, 2005. 
U.S. Rail Freight Industry

Table 3: Railroad Productivity, 1995-2004

\begin{tabular}{lcccccc}
\hline & $\mathbf{1 9 9 5}$ & $\mathbf{2 0 0 0}$ & $\mathbf{2 0 0 1}$ & $\mathbf{2 0 0 2}$ & $\mathbf{2 0 0 3}$ & $\mathbf{2 0 0 4}$ \\
\hline Output Index (Table 1) & 100 & 121 & 127 & 131 & 136 & 150 \\
Input Index (Table 2) & 100 & 89.2 & 87.1 & 87.8 & 90.0 & 95.3 \\
Productivity Index & 100 & 136 & 146 & 148 & 151 & 157 \\
\hline
\end{tabular}

The productivity index is estimated as the ratio of the output index to the input index.

Improvements in productivity do not necessarily translate into financial improvements, which also depend on trends in rates and in unit costs. If productivity improves and rail prices keep pace with inflation in costs, then profits also improve. Table 4 provides summary comparisons for productivity, prices, and profits for the entire period 1995-2004. Productivity rose sharply during this period, as shown in the first row of the table. However, prices not only failed to keep pace with inflation, but declined. Taking 1995 as the base year, the ratio of the price index (Table 1) to the Railroad Cost Recovery Index (Table 2) fell to 0.63 by 2004 . The overall effect on profitability was very small, as is evident in the combined index, which is the product of the factors shown in the first two lines of the table.

Table 4: Productivity, Prices, and Profits, 1995-2004

\begin{tabular}{lcccccccccc}
\hline & 1995 & $\mathbf{1 9 9 6}$ & $\mathbf{1 9 9 7}$ & $\mathbf{1 9 9 8}$ & $\mathbf{1 9 9 9}$ & $\mathbf{2 0 0 0}$ & $\mathbf{2 0 0 1}$ & $\mathbf{2 0 0 2}$ & $\mathbf{2 0 0 3}$ & $\mathbf{2 0 0 4}$ \\
\hline $\begin{array}{l}\text { Productivity } \\
\begin{array}{l}\text { Price Index/ } \\
\text { Cost Index }\end{array}\end{array}$ & 100 & 115 & 118 & 119 & 124 & 136 & 146 & 148 & 151 & 157 \\
$\begin{array}{l}\text { Combined Index } \\
\text { NROI (billion) }\end{array}$ & 100 & .94 & .90 & .86 & .84 & 0.74 & 0.70 & 0.69 & 0.66 & .63 \\
& $\$ 2.9$ & $\$ 4.3$ & $\$ 4.0$ & $\$ 3.7$ & $\$ 4.0$ & $\$ 3.9$ & $\$ 4.1$ & $\$ 4.2$ & $\$ 4.1$ & $\$ 4.1$ \\
\hline
\end{tabular}

Data source: AAR, Railroad Facts, 2005.

This analysis confirms the results of the previous study (Martland 1999). Overall productivity continued to rise in the rail industry through 2004, but the benefits to the railroads were again offset by declines in rail rates. As a result, net railway operating income (NROI) peaked in 1996 at \$4.34 billion, but was lower in each of the next seven years.

\section{Have Rates Really Declined?}

The STB estimated that the reductions in rail rates since deregulation in 1980 were equivalent to nearly \$32 billion in 1999. This number was consistent with the conclusion of Martland (1999) that rate reductions had amounted to $\$ 25$ billion in 1995. Several challenges have been made to the STB's methodology - and by implication to the similar methodology used in this research. For example, see the strongly negative reaction to the STB study reported in Traffic World (Wilner 2000) and the equally strong support for the STB results published subsequently (Rockey 2001).

Shippers are generally less concerned with absolute rates than with equitable rates, i.e., their rates versus the rates offered to their competitors. It appears that rate differentials - the differences in rail rates paid by different customers for similar services - have increased for some, even while rate levels have declined for most. This can result in what customers regard as inequitable. For example, 
two railroad customers may be competing with each other to sell their products, which they ship by rail. Customer A's rates may have declined by $10 \%$ over the past 25 years, but Customer B's rates may have declined by $40 \%$. In this case, the rate differential has increased and Customer A may, as a result, lose some of its market share to Customer B. The STB response to such concerns was that deregulation has provided railroads the freedom to set differential rates depending upon the value of the service to customers and the extent of competition for the product (Surface Transportation Board 2000). Therefore, some rates may well have risen or declined only slightly, but the STB concluded that the overwhelming evidence is that average rates have fallen.

Another complaint is that there has been a shift in traffic mix that results in a lower average rate, even though the rates may have been the same or higher for each traffic class. The STB addressed this issue by breaking out separate rate indices for eastern and western traffic; while the western traffic did indeed show a greater decline than in the east, the declines in both regions were steady and substantial. The STB also noted that average revenue per ton declined or remained stable for most of the major traffic groups after deregulation despite increases in the average length of haul (Surface Transportation Board 2000).

A more serious contention is that the services provided by the railroads are not the same services that were provided 10 or 20 years ago. There are several important concerns. First, the railroads have shifted much of the burden of fleet ownership to the customers. In 1980, car companies and rail customers owned 26\% of the car fleet, but their share of the fleet increased to $37 \%$ by 1990 and $50 \%$ by 2000 (AAR 2005). The net effect over this 20 -year period was that customers purchased more than a quarter of a million freight cars that in prior days might have been purchased by the railroads. At an average cost per car of about \$50,000 over most of this period (as reported in Railroad Facts), it is clear that shippers and car companies made an investment of $\$ 10$ to $\$ 15$ billion in equipment. Shifting ownership and maintenance responsibilities to customers surely increased their costs. However, the STB concluded that the total cost would amount to only about $\$ 3$ billion per year, which is a small fraction of the annual savings of more than $\$ 30$ billion that were achieved from productivity savings in the rail industry and passed on to customers in the form of lower rates.

Another valid concern is that the railroads achieved a considerable portion of their productivity savings through rationalization of the network and structuring rates so as to promote multi-car shipments and unit trains. To take advantage of these services, some customers had to invest in facilities capable of handling much larger shipments, while others - especially farmers - complained that their costs rose for bringing their product to the rail head. This complaint is true, as the cost savings from line abandonment and facility consolidation are offset to some extent by the added costs to shippers who may face higher costs for storage or for access to more distant rail shipping points. The reductions in rail rates, therefore, do not equal the savings to shippers who may face higher logistics expense elsewhere.

A final valid concern is that service levels have not been constant. During the late 1990s, the rail industry suffered a series of prolonged periods of congestion that were highlighted in the general business press and generally attributed to difficulties in mergers (Jesdanum 1999, Machalaba 1999, and Gallagher 2002). Another explanation could be that decades of down-sizing coupled with strong growth in train-miles had put the industry on a course where the shrinking facilities would at some point be unable to handle the incremental traffic. Whatever the ultimate cause, there were major service complaints following Union Pacific's mergers, first with Chicago \& Northwestern and then with Southern Pacific; a couple of bad winters led to serious problems for grain exports in the northwest, especially for the Canadian ports; the CSX and Norfolk Southern acquisition and the division of Conrail led to more problems. Congestion increases trip times, reduces reliability, forces customers to pay more for inventory or use more expensive modes, and causes railroads to lose business or hurt relationships with their customers.

Taking all of these factors together, it is clear that the price reductions cited above, while real to the rail industry, have to some extent been offset by costs shifted to rail customers. The railroads 
have also achieved some of their productivity gains at the expense of losing capacity in the system, so that periods of congestion have become major concerns for customers and possibly placed major constraints on growth for the industry. Still, it is clear that rail rates have indeed declined by amounts that are sufficient to explain why the more than \$25 billion in annual productivity improvements had not, as of 2004, resulted in higher rail profitability. The continuing pressures of the competitive freight transport market made it very difficult for the rail industry to capture long-term financial benefits from their very successful efforts to improve productivity.

\section{SOURCES OF PRODUCTIVITY IMPROVEMENT, 1995-2004}

The aggregate analysis shown above cannot shed much light on the sources of productivity improvement. More detailed analysis is necessary to estimate the importance of specific technological or institutional factors influencing productivity improvement. This section considers the direct effects of such things as heavier trains, more efficient equipment, improved maintenance technologies, and advances in computers and communications. Together, these innovations have provided benefits that are sufficient to explain the cost reductions and productivity improvements identified in the aggregate analysis.

\section{Service Units per Unit of Output}

Heavy haul railroading and intermodalism are two long-term trends in equipment and traffic mix that have allowed the railroads to move more freight with fewer resources. Heavy haul railroading refers to a series of technological and operating improvements that allow the use of larger cars, more powerful locomotives, and longer trains. The growth of intermodal transportation has resulted in a shift in traffic mix that favors lighter shipments that do not require complex handling in classification yards or movement on light density lines. Both trends reduce the costs per unit of output.

Larger, lighter cars. Larger cars carry more freight, and the capacity of cars rises faster than their cost or weight. With larger cars, the ratio of gross tonnage (weight of equipment plus contents) to net tonnage (weight of contents) declines. Better car designs and use of aluminum or other lightweight materials have also reduced this ratio, thereby leading to savings in fuel consumption, track maintenance, and train crews by allowing the same amount of freight to be carried in fewer trains.

Unit trains. A unit train can be used to transport coal, grain, or ore from a single origin to a single destination, avoiding the need to handle cars at intermediate yards. With unit trains, costs per tonmile decline because fewer switching yards are needed, much less time is spent for each trip (e.g., cycle times of a week or so versus two to three weeks for traditional single car shipments), and locomotive utilization is higher.

Shift from general service to intermodal. Intermodal movement of trailers or containers replaces complex and expensive terminal switching by railroads with more efficient short haul truck moves. Intermodal trains provide service to a hundred or so major intermodal terminals, while traditional rail service involved more than a thousand classification yards. Therefore, increases in intermodal traffic, plus declines in general merchandise, reduce the capacity needed in classification yards.

Shift from TOFC/COFC to Double-Stack Intermodal Trains. Further improvements in intermodal service have been obtained by using double-stack container trains. A double-stack train carries almost twice as many containers as a standard COFC (Container on Flat Car) or TOFC (Trailer on Flat Car) train. Hence, there are dramatic savings in crew costs and benefits in terms of line capacity. Moreover, the empty weight of double-stack trains is low, providing benefits in terms of reduced equipment cost, lower fuel costs, and lower track maintenance. 
The benefits from these kinds of productivity improvements were estimated by a three-step process. The first step was to calculate the number of gross ton-miles, train-miles, car-miles, and carloads per unit of output for each year (i.e., the output index in Table 1). These service units (SU) were selected because they reflect key aspects of rail operations that are affected by heavy haul railroading and intermodalism. The next step was to calculate the number of gross ton-miles, train-miles, car-miles, and carloads that would have been required for each year if the ratios of service units per unit of output were the same as in the base year. The third step was to calculate cost savings by multiplying the reductions in service units by estimated unit costs for the base year of 19952:

- $\quad \$ 5 /$ train-mile

- $\$ 0.06 /$ freight car-mile

- $\$ 2.50 / 1000$ gross ton-miles

- $\$ 150 /$ load

Table 5 shows the benefits estimated for the period 1995 to 2004. If the service units had increased proportionately with the output measure shown in Table 1, then annual costs would have been $\$ 3.6$ billion higher by 2004, which represents an annual improvement of $\$ 0.4$ billion for this period. For comparison, the results of Martland (1999) are shown for 1995 versus 1983. That study included savings from yard switching hours, which are no longer reported in Railroad Facts and were not included for the current period.

Table 5: Estimated Savings from Changes in SU/Unit of Output

\begin{tabular}{lccccc}
\hline \multicolumn{1}{c}{ Service Unit } & Unit Cost & $\begin{array}{c}\text { SU/Output, } \\
\mathbf{2 0 0 4}\end{array}$ & $\begin{array}{c}\text { Reduction } \\
\text { in SU 2004 }\end{array}$ & $\begin{array}{c}\text { SU Savings } \\
\mathbf{2 0 0 4} \text { v. 1995 }\end{array}$ & $\begin{array}{c}\text { SU Savings } \\
\mathbf{1 9 9 5} \text { v. 1983 }\end{array}$ \\
\hline Train-miles & $\$ 5$ & .779 & 152 million & $\$ 0.8$ billion & $\$ 1.0$ billion \\
Car-miles & $\$ 0.06$ & .811 & 8.62 billion & $\$ 0.5$ billion & $\$ 0.6$ billion \\
Carloads & $\$ 150$ & .846 & 5.46 million & $\$ 0.8$ billion & $\$ 1.9$ billion \\
Gross Ton-miles & $\$ 2.50$ per & .849 & 590 billion & $\$ 1.5$ billion & $\$ 1.5$ billion \\
Yard Switching & 1000 & $\$ 100$ & & & $\begin{array}{c}\text { Not } \\
\text { Hours }\end{array}$ \\
Total & & & & $\$ 1.7$ billion \\
Savings/year & & & & $\$ 0.40$ billion & $\$ 0.55$ billion \\
\hline
\end{tabular}

Data Sources: service units from AAR (2005); unit costs from Martland (1999).

\section{Fuel Efficiency}

The next step in the detailed productivity analysis is to consider changes in the amount of resources required per service unit. This paper considers three major resources where there were continuing productivity improvements: fuel, employees, and track. The paper does not consider freight cars, as this was not found to be a source of productivity improvement over the period in question. For each resource, it is possible to consider changes in the amount of resources required and the price of the resource. This section considers fuel efficiency. Subsequent sections address labor and track. 


\section{U.S. Rail Freight Industry}

The introduction of larger, more efficient locomotives helped railroads to improve fuel efficiency, as did the increase in vehicle capacity mentioned earlier. The first three rows of Table 6 show the gallons of fuel used by the Class I railroads, the average price per gallon, and the revenue ton-miles (RTM) per gallon. The next two rows show how increases in fuel efficiency led to reductions in fuel consumption and fuel cost, assuming the 1995 price of $\$ 0.60$ per gallon. The reduction in fuel usage was estimated as the product of revenue ton-miles in each year multiplied by the change in gallons per revenue ton-mile relative to the base year of 1995. The next row shows the effect of the increase in fuel prices, which reached \$1.07 in 2004. The effect of the change in fuel price was estimated as the actual gallons consumed in each year multiplied by the change in the price of fuel per gallon relative to the price in the base year. The combined effect was negative, as the price increases for fuel more than offset all the fuel economy gains. In contrast, in the 12-year period before 1995, fuel efficiency and declining fuel prices provided a net benefit to the railroads; fuel costs in 1995 would have been $\$ 0.9$ billion higher if fuel efficiency and fuel costs had remained at 1984 levels.

Table 6: Fuel Efficiency and Fuel Cost, 1995-2004

\begin{tabular}{lcccccc}
\hline & $\mathbf{1 9 9 5}$ & $\mathbf{2 0 0 0}$ & $\mathbf{2 0 0 1}$ & $\mathbf{2 0 0 2}$ & $\mathbf{2 0 0 3}$ & $\mathbf{2 0 0 4}$ \\
\hline Gallons (million) & 3480 & 3700 & 3710 & 3730 & 3826 & 4059 \\
Price/gallon & $\$ 0.60$ & $\$ 0.87$ & $\$ 0.86$ & $\$ 0.73$ & $\$ 0.89$ & $\$ 1.07$ \\
RTM/gallon & 375 & 396 & 403 & 404 & 405 & 410 \\
Reduction in gallons & 0 & 206 & 274 & 286 & 307 & 371 \\
$\begin{array}{l}\text { Benefit @ 1995 price } \\
\text { Effect of change in } \\
\text { fuel price (million) }\end{array}$ & 0 & $\$ 124$ & $\$ 164$ & $\$ 171$ & $\$ 184$ & $\$ 223$ \\
$\begin{array}{l}\text { Net benefit (million) } \\
\text { Ret }\end{array}$ & 0 & $(\$ 1016)$ & $(\$ 947)$ & $(\$ 497)$ & $(\$ 1109)$ & $(\$ 1,907)$ \\
\hline
\end{tabular}

Data Source: AAR, Railroad Facts, 2005.

\section{Employee Productivity}

Employee productivity was estimated using a methodology developed by Banner and Brosnan (1983) that was applied in earlier studies of railroad productivity (Martland 1989 and 1999). If labor productivity was unchanged, then the number of employees required would vary directly with the relevant service unit. ${ }^{3}$ The Association of American Railroads (in Railroad Facts) reports the number of employees and their average compensation by major category as well as the major service units. Thus, it is possible to estimate labor productivity for any particular year and the changes in productivity over a period of years. The first three columns of Table 7 show the service units used for each category, the change in service units between 1995 and 2004, and the change in employees over the same period. If there had been no changes in employee productivity, then the percentage change in employees would have been the same as the percentage change in the relevant service unit. In fact, employment fell in all but one category despite increases in the number of service units. The number of additional employees that would have been required if the ratio of employees to service unit (EPSU) was the same in 2004 as it was in the base year of 1995 was calculated as follows: 
Added employees $=$ SU2004 * $($ EPSU95 - EPSU04)

The cost savings were estimated by multiplying the reduction in employees in each category by their average annual wages in 1995 (last column of Table 7).

Table 7: Improvements in Employee Productivity, 1995-2004

\begin{tabular}{|c|c|c|c|c|}
\hline & $\begin{array}{c}\text { Service } \\
\text { Unit }\end{array}$ & $\begin{array}{c}\text { Increase in } \\
\text { Service Units } \\
\text { 1995-2004 }\end{array}$ & $\begin{array}{l}\text { Change in } \\
\text { Employment }\end{array}$ & $\begin{array}{c}2004 \text { Cost Saving } \\
\text { @ } 1995 \text { wages } \\
\text { (\$Billions) }\end{array}$ \\
\hline $\begin{array}{l}\text { Executives, } \\
\text { Officials and } \\
\text { staff }\end{array}$ & Carloads & $27 \%$ & $-15 \%$ & $\$ 0.35$ \\
\hline $\begin{array}{l}\text { Professional \& } \\
\text { Administration }\end{array}$ & Carloads & $27 \%$ & $-49 \%$ & $\$ 0.910$ \\
\hline $\begin{array}{l}\text { Maintenance } \\
\text { of Way \& } \\
\text { Structures }\end{array}$ & $\begin{array}{l}\text { Revenue } \\
\text { ton-miles }\end{array}$ & $27 \%$ & $-16 \%$ & $\$ 0.67$ \\
\hline $\begin{array}{l}\text { Maintenance of } \\
\text { Equipment }\end{array}$ & Car-miles & $22 \%$ & $-21 \%$ & $\$ 0.56$ \\
\hline $\begin{array}{l}\text { Transportation, } \\
\text { other than Train } \\
\text { \& Engine }\end{array}$ & Train-miles & $17 \%$ & $-22 \%$ & $\$ 0.17$ \\
\hline $\begin{array}{l}\text { Transportation, } \\
\text { Train \& Engine }\end{array}$ & Train-miles & $17 \%$ & $1 \%$ & $\$ 0.57$ \\
\hline Total ( $\$$ billions) & & & & $\$ 3.23$ \\
\hline
\end{tabular}

Data Source: AAR, Railroad Facts, 2005.

These results indicate a continuing improvement in productivity in each area, with a total benefit of $\$ 3$ billion per year by the end of the period. However, if these results are compared with those for 1983-1995, the rate of improvement was slower, as is evident by considering the three largest categories of savings:

Train Crew Productivity. Between 1983 and 1995, the industry implemented reductions in crew consist and changes in labor agreements that produced a dramatic reduction in the number of people required to run trains. As described in the earlier study, the average train and engine (T\&E) employees per 10,000 train-miles dropped from 2.75 in 1983 to 1.39 in 1995, leading to a benefit of nearly $\$ 5$ billion per year by 1995 . The decline continued, but at a much slower rate to 1.16 by 2003, and then increased to 1.20 in 2004. As of 2004, the additional benefit was only $\$ 0.57$ billion dollars/year at 1995 wage rates. The annual incremental benefits were less than $\$ 0.1$ billion per year after 1995 compared with \$0.4 billion per year in the 1983-1995 period.

Office Automation. Between 1983 and 1995, the number of employees in the professional \& administrative category declined from 68,000 to 27,000 for a savings of $\$ 1.8$ billion. If that number were adjusted for the $25 \%$ increase in carloads handled by 1995 , then the savings would have been increased to $\$ 2.5$ billion, i.e., over $\$ 0.2$ billion per year for the 12 -year period. The number of professional \& administrative employees continued to decline through 2004, but at a slower pace, resulting in savings of $\$ 0.1$ billion per year (i.e., $\$ 0.9$ billion savings at 1995 wage rates over the nine years from 1995 to 2004). 
Maintenance of Way (MOW). Between 1983 and 1995, the number of employees in this category declined nearly $40 \%$, from 64,000 to 40,000 , despite an increase in ton-miles of nearly $60 \%$. If the number of employees per ton-mile had remained the same, 2.5 times as many employees would have been needed in 1995 as in 1983. At the average wage in 1995, the payroll for MOW would have jumped from $\$ 1.56$ billion to $\$ 3.8$ billion. In 2004, if the number of employees per ton-mile had remained the same as in 1995, then the percentage increase in MOW employees would have been the same as the $27 \%$ increase in ton-miles. To put this into more understandable terms, employment was declining at 3\% per year during the 1983-1995 period when ton-miles were growing at 4\% per year; this led to a very large increase in MOW productivity. In the more recent 1995-2004 period, employment declined at a rate of $2 \%$ per year while ton-miles were growing at a rate of $3 \%$ per year. The work force continued to decline while the demand on the track structure continued to grow, but the rate of productivity improvement and the rate of traffic growth were both lower than in the earlier period.

\section{Facility Rationalization}

The U.S. rail network reached its largest extent in the 1920s and has been declining ever since. The pace of decline was accelerated during the 1980s, but declined by the end of the 1990s. Table 8 shows the miles of route and track owned by the Class I railroads. ${ }^{4}$ This exhibit starts with the peak in 1929 and shows the continuous decline since then.

Table 8: Miles of Route and Track Owned, Class I Carriers

\begin{tabular}{ccc}
\hline Year & Route-Miles & Track-Miles \\
\hline 1929 & 229,530 & 381,417 \\
1939 & 220,915 & 360,174 \\
1955 & 211,459 & 350,217 \\
1965 & 199,798 & 324,788 \\
1975 & 191,520 & 310,941 \\
1985 & 145,764 & 242,320 \\
1995 & 108,264 & 180,419 \\
2000 & 99,250 & 168,535 \\
2004 & 97,662 & 167,312 \\
\hline
\end{tabular}

Source: AAR, Railroad Facts, 2005.

Between 1975 and 1995, the route-miles owned by the Class I railroads dropped by 4,000 miles per year, while the track-miles dropped by more than 6,000 miles per year. The reduction in route-miles owned resulted from the abandonment of branch lines and spinning off portions of the network to be operated by local or regional carriers. The greater reduction in track-miles reflects the elimination of yard tracks and the reduction of tracks in some multi-track segments. Between 1995 and 2004, the rate of route rationalization declined. There was a reduction of only about 1,100 miles per year in route-miles and a reduction of barely 1,500 miles per year in track miles. The slowdown in rationalization is an indicator that the opportunities for eliminating redundant track were declining. In some well-publicized cases, such as the UP's coal route in Nebraska, railroads found that they needed to add a second or third main line in order to handle record tonnages. In many more cases, they added sidings to allow more frequent trains or extended sidings to allow longer trains. 


\section{Summary of Productivity Benefits}

Table 9 summarizes the benefits described in this section. It is important to understand that the savings in the "total" column are the total savings for one year based upon the cumulative productivity improvements made since the base year. Thus, in 1995, costs would have been $\$ 18$ billion higher if productivity in these areas had been the same as in 1983. Likewise, in 2004, costs (in 1995 dollars) would have been $\$ 7$ billion higher if productivity had been at the same level as in 1995 . These benefits are additive, so that the annual benefits would have been greater than $\$ 25$ billion by 2004 if compared to a base year of 1983. The figures in the "Annual" columns represent the rate of increase of annual benefits over the period. The pace of productivity improvement declined by nearly $50 \%$, while increases in fuel prices became a much more significant factor affecting total expenditures for fuel.

Table 9: Summary of Annual Cost Reductions Resulting From Productivity Improvements by U. S. Class I Railroads, 1983 to 2004 (in billions of 1995 dollars)

\begin{tabular}{|c|c|c|c|c|}
\hline & $\begin{array}{l}1995 \text { v. } 1983 \\
\text { Total }\end{array}$ & $\begin{array}{l}1995 \text { v. } 1983 \\
\text { Annual }\end{array}$ & $\begin{array}{l}2004 \text { v. } 1995 \\
\text { Total }\end{array}$ & $\begin{array}{c}2004 \text { v. } 1995 \\
\text { Annual }\end{array}$ \\
\hline $\begin{array}{l}\text { Reduction in SU per unit of } \\
\text { Output }\end{array}$ & $\$ 6.7$ & $\$ 0.56$ & $\$ 4.3$ & $\$ 0.48$ \\
\hline $\begin{array}{l}\text { MOW Productivity (Labor } \\
\text { only) }\end{array}$ & $\$ 2.2$ & $\$ 0.18$ & $\$ 0.67$ & $\$ 0.074$ \\
\hline MOW Productivity (Other) & $\$ 2.8$ & $\$ 0.23$ & $\$ 0.9 *$ & $\$ 0.1$ \\
\hline Office Technology & $\$ 2.5 * *$ & $\$ 0.21$ & $\$ 0.91$ & $\$ 0.1$ \\
\hline T\&E Employees & $\$ 3.3$ & $\$ 0.27$ & $\$ 0.74$ & $\$ 0.08$ \\
\hline $\begin{array}{l}\text { Fuel Efficiency (@ } 1995 \\
\text { price of } \$ 0.60 / \text { gallon)*** }\end{array}$ & $\$ 0.54$ & $\$ 0.045$ & $\$ 0.22$ & $\$ 0.024$ \\
\hline Total, Productivity Effect & $\$ 18$ & $\$ 1.5 / \mathrm{yr}$ & $\$ 7$ & $\$ 0.8 / \mathrm{yr}$ \\
\hline Fuel Price Effect & $(\$ 0.8)$ & $(\$ 0.07)$ & $(\$ 1.9)$ & $(\$ 0.2)$ \\
\hline $\begin{array}{l}\text { Total, Productivity Plus } \\
\text { Fuel Price Change }\end{array}$ & $\$ 17$ & $\$ 1.5 / \mathrm{yr}$ & $\$ 5$ & $\$ 0.6 . / \mathrm{yr}$ \\
\hline
\end{tabular}

Data Sources: AAR Railroad Facts, various years; Martland (1999)

* The improvement in MOW productivity for 1995 was based upon a very detailed analysis undertaken at that time. The estimate for 2004 assumes a similar ratio between savings for labor and savings for other inputs, which would include savings in materials and in track machinery based upon longer lives for track components.

** The office technology savings were increased from \$1.8 billion in Martland (1999) to \$2.5 billion to be consistent with the methodology used in the other areas, as described in the text.

*** Fuel savings are based upon changes in RTM/gallon rather than gallons per unit of output. 
U.S. Rail Freight Industry

\section{PRODUCTIVITY AND PROFITABILITY}

Although the Class I railroads achieved very substantial improvements in productivity between 1995 and 2004, they were unable to translate these improvements into steady increases in any of the commonly used financial measures (Table 10). If net railway operating income (NROI) is viewed in constant dollars, there was no sustained improvement over this period, nor was performance superior to what was achieved in the early 1980s. The NROI was $\$ 2.5$ billion in 1984 , which would be $\$ 3.6$ billion in 1995 dollars. The same stable performance is evident with respect to return on net investment and rate of return on shareholders' equity. If anything, all of these financial measures peaked some time between 1994 and 1996 and declined through 2004.

Table 10: Financial Performance of the U.S. Class I Railroads, 1990-2004

\begin{tabular}{|c|c|c|c|c|c|}
\hline Year & $\begin{array}{l}\text { NROI } \\
\text { \$billion }\end{array}$ & $\begin{array}{c}\text { NROI * } \\
1995 \$ \\
\text { Sbillion }\end{array}$ & $\begin{array}{c}\text { Return } \\
\text { on Net } \\
\text { Investment }\end{array}$ & $\begin{array}{c}\text { Return on } \\
\text { Equity }\end{array}$ & $\begin{array}{c}\text { Capital } \\
\text { Expenditures } \\
\text { \$billion } \\
\end{array}$ \\
\hline 1990 & $\$ 2.68$ & $\$ 3.03$ & $8.11 \%$ & $8.18 \%$ & $\$ 3.64$ \\
\hline 1991 & $(0.04)$ & $(0.04)$ & Nil & Nil & 3.44 \\
\hline 1992 & 1.95 & 2.09 & $6.3 \%$ & $7.93 \%$ & 3.61 \\
\hline 1993 & 2.52 & 2.63 & $7.06 \%$ & $9.38 \%$ & 4.18 \\
\hline 1994 & 3.39 & 3.47 & $9.37 \%$ & $12.68 \%$ & 4.89 \\
\hline 1995 & 2.86 & 2.86 & $7.04 \%$ & $7.93 \%$ & 5.99 \\
\hline 1996 & 4.34 & 4.25 & $9.36 \%$ & $12.21 \%$ & 6.10 \\
\hline 1997 & 3.98 & 3.83 & $7.56 \%$ & $9.27 \%$ & 6.27 \\
\hline 1998 & 3.67 & 3.79 & $7.00 \%$ & $8.69 \%$ & 7.20 \\
\hline 1999 & 4.05 & 3.67 & $6.93 \%$ & $9.36 \%$ & 6.63 \\
\hline 2000 & 3.92 & 3.68 & $6.48 \%$ & $7.95 \%$ & 6.06 \\
\hline 2001 & 4.11 & 3.67 & $6.85 \%$ & $7.96 \%$ & 5.43 \\
\hline 2002 & 4.25 & 3.77 & $7.04 \%$ & $8.28 \%$ & 5.67 \\
\hline 2003 & 4.01 & 3.55 & $6.33 \%$ & $6.65 \%$ & 5.86 \\
\hline 2004 & 4.15 & 3.52 & $6.12 \%$ & $6.16 \%$ & 6.24 \\
\hline
\end{tabular}

Data Sources: AAR Railroad Facts various years

* Deflated using the same approach used by the AAR to deflate revenue per ton-mile

Table 10 also documents the increases in capital expenditures over this period, which is another financial concern. Capital expenditures by the Class I railroads first exceeded \$5 billion in 1995; as of 2004, they had exceeded that amount in every subsequent year. Capital expenditures peaked in 1998 when railroads were struggling to deal with their capacity and service problems. Over long periods of time, capital expenditures for track and equipment will tend to be proportional to traffic volumes, especially as measured by ton-miles. Rail and ties must be renewed, and additional cars and locomotives will be needed to maintain and expand the size of the fleet. Between 1983 and 1995, an average of 26,000 cars were added to the fleet each year; expenditures for freight cars were limited during this period because there had been a large surplus of general equipment at the beginning. By the mid-1990s, these surpluses were largely eliminated, and equipment purchases 
accelerated to an average of 49,000 freight cars per year between 1996 and 2004 (Railroad Facts various years). It is likely that capital expenditures will continue to rise if traffic increases. ${ }^{5}$ How that capital will be raised will be a very serious problem for the industry.

\section{NEW TRENDS IN 2005}

This paper was originally intended to address productivity, prices, and profitability only through 2004, the most recent year for which all of the relevant data were available at the time this paper was written. However, trends that had continued for 20 years came to an end in 2004, prices rose and profitability increased to record levels in 2005. Table 11 provides illustrative data for the four largest U.S. railroads. While this is not exactly the same information used in the prior analysis, the main trends are very clearly evident. The first line shows that total traffic volume increased by about $2 \%$, whether measured by carloads or revenue ton-miles. As shown in Table 1 , output (as used in this paper) has been rising faster than either tons or ton-miles, so that output likely increased by more than $2 \%$ in 2005 . The increases in revenue were much greater, averaging $13 \%$ for these railroads. If we assume that output increased at $3 \%$, then the increase in price per unit of output would be approximately $10 \%$ (estimated as 1.13/1.03). Operating expenses increased more rapidly than either carloads or ton-miles. The average increase of $7.6 \%$ was approximately the same as the 8\% increase in rail costs in 2005 (Surface Transportation Board 2006). The operating ratio - the ratio of operating expense to operating revenue - is a financial indicator commonly used by railroads and investment analysts. Since revenues rose faster than costs in 2005, the operating ratio declined for each of these railroads, and net income nearly doubled. Higher prices and improved financial performance were also reported by these railroads for the first half of 2006.

Table 11: Selected Operating and Financial Measures for the Largest U.S. Railroads in 2005

\begin{tabular}{lccccc}
\hline & BNSF & CSX & NS & UP & Total \\
\hline Carloads & $5.1 \%$ & $-0.5 \%$ & $4.3 \%$ & $0.9 \%$ & $2.1 \%$ \\
Ton-Miles & $4.5 \%$ & $3.2 \%$ & $2.3 \%$ & $0.5 \%$ & $2.2 \%$ \\
Revenue & $17.4 \%$ & $7.2 \%$ & $16.6 \%$ & $7.9 \%$ & $13.1 \%$ \\
Operating Expense & $8.7 \%$ & $0.3 \%$ & $14.3 \%$ & $7.9 \%$ & $7.6 \%$ \\
Operating Ratio & $-8.9 \%$ & $-6.4 \%$ & $-2.0 \%$ & $-2.9 \%$ & $-5.1 \%$ \\
Net Income & $94 \%$ & $238 \%$ & $40 \%$ & $70 \%$ & $88 \%$ \\
\hline
\end{tabular}

Data Source: Annual Reports, Burlington Northern Santa Fe, CSX, Norfolk Southern, Union Pacific

\section{SUMMARY AND CONCLUSIONS}

As predicted in prior research, most of the trends that followed deregulation of the rail industry continued during the period 1995 to 2004. Productivity improved, but the rate of improvement declined; the reduction in real rail rates continued, and financial performance deteriorated. The industry that in 1995 was considered by many to be in the midst of a renaissance, found itself beset with problems related to service and capacity and still struggling to cover their cost of capital. By 2004, the industry found itself in a situation where rapid growth in traffic had led to serious capacity and service problems, both of which detracted from the value of rail service to customers.

With respect to pricing, the lack of capacity proved - at least between 2004 and 2006 - to be more powerful than intra-rail competition, with the ironic result that the ability to raise rates only came during a period of deteriorating rail service. Higher prices were possible in part because of rising marginal costs as the system approached capacity, and in part because of a change in the 
industry's competitive position versus intercity trucking. Since fuel costs have a greater impact on trucks than on the more energy efficient railroads, the rapid rise in fuel costs provided an important competitive advantage for the rail industry in 2005 and 2006.

Rail capacity has become a matter of concern to the public, reflecting frustration with highway congestion and a desire to move trucks off the highways. The ability of the rail network to handle more traffic has also become a major issue for public officials. Many of them question the willingness and ability of the industry to make the investments that will be required if rail is to maintain or increase its market share (e.g., Grenzback et al. 2003). Given the public's interest in these issues, it is uncertain whether the recent pattern of declining rail service, restricted rail capacity, and rising rail rates will be sustainable.

Rail capacity is simply too important a concern for public agencies to ignore. And they are not ignoring it. In April 2006, the U.S. House Sub-Committee on Rail conducted a hearing on “The U.S. Rail Capacity Crunch,” demonstrating their interest in capacity, equity in pricing, service quality, and the common carrier obligation. In July 2006, the bipartisan "Freight Rail Infrastructure Capacity Expansion Act” was introduced in the U.S. Senate. If enacted, this bill would provide a $25 \%$ tax credit for investments in rail infrastructure (AAR 2006b). Enhanced rail system capacity is therefore likely to be a major public policy issue in the next decade as the public and customers push for a system that may well be more than the industry on its own can afford. The rail industry and public agencies will have to work more closely together to achieve what they all desire - an efficient, profitable rail system that is able to provide quality service, attract more traffic, and help alleviate problems related to highway congestion, dependence upon imported oil, and environmental quality.

\section{Endnotes}

1. The revenue per ton-mile is not a price index, as it does not provide a comparison of prices charged for similar shipments. However, any distortions introduced by using this extrapolation for 2000-2004 are believed to be minor compared with the magnitude of the changes in prices and productivity over the last 10 to 20 years.

2. The service unit costing approach has commonly been used for decades in service planning and engineering studies to evaluate tradeoffs involving operating plans, track structure, and equipment. The unit costs can be estimated in two ways. One way is to allocate each category of expense for a base year to the most relevant service unit, e.g., track expense can be related to gross ton-miles. Another way is to estimate unit costs for what are believed to be the most important cost drivers. One earlier study allocated expenses to eight service units for a base year of 1978 as part of an analysis of productivity changes in the rail industry between 1972 and 1983 (Martland 1989). The most important of these service units were used in an expanded study of productivity changes between 1965 and 1995 (Martland 1999). That study used the unit costs from 1978, which were found to be reasonable for 1995, as the effects of inflation were offset by improvements in technology and in labor productivity The AAR no longer reports yard hours, so that portion of the analysis was dropped from the current study.

3. Engineering and operating considerations clearly indicate that train-miles are relevant for train crews, ton-miles for maintenance of way, and car-miles for maintenance of equipment. Other transportation employees would ideally be related to yard and train-switching, but these service unites are no longer reported by the AAR. The choices of appropriate service units for the other two categories are less clear as the number of professionals, clerks, and executives conceivably could be related to tons, carloads, shipments, or a combination of various factors. Carloads was deemed to be the best measure because most transactions relate more to cars handled than to the other measures. 
4. Route-miles is a measure of the distance between points served by the railroad. Track-miles measures the length of the tracks, taking into account passing sidings, sections of multiple track, and yard tracks.

5. In 2005, the Class I freight railroads invested $\$ 6.9$ billion in capital expenditures. In 2006, they planned to spend $\$ 8.3$ billion (AAR 2006a).

\section{References}

Association of American Railroads. Railroad Facts. Association of American Railroads, Washington D.C., various editions, 1981 to 2005.

Association of American Railroads. “Major Freight Railroads to Invest \$8.3 Billion in Infrastructure in 2006.” Association of American Railroads, Washington D.C., March 16, 2006.

Association of American Railroads. "Senate Bill Addresses Growing Freight Capacity Crunch." Association of American Railroads, Washington D.C., July 27, 2006.

Banner, Paul H. and Francis D. Brosnan, Jr. “Labor Productivity in Rail Transport.” Transportation Research Record 917. Transportation Research Board, Washington, D.C., 1983.

Dennis, Scott M. “A Primer on Railroad Price Indexes.” Journal of Transportation Law, Logistics, and Policy 72(3), (2005): 312 -327.

Gallamore, Robert E. "Perspectives and Prospects for American Railroad Infrastructure." Infrastructure 3(4), (1998).

Gallamore, Robert E. "Regulation and Innovation: Lessons from the American Railroad Industry." J. Gomez-Ibanez, W. Tye, and C. Winston eds. Essays in Transportation Economics and Policy. Washington,D.C.: Brookings Institution Press (1999): 493-530.

Gallagher, John. "No Rate Crisis? GAO: Rail Rates Continued to Decline Despite Late '90s Rail Service Disruptions.” Traffic World, July 8, 2002, p. 25.

Grenzback, L., A. Meyers, J. Bryan, B. Muten, and C. Martland. Freight Rail Bottom Line Report. American Association of State Highway and Transportation Officials, 2004.

Harper, Edwin L. "Opening Remarks at the 1996 AREA Regional Conference, Mexico City, Mexico.” AREA Bulletin 758, (1996): 753-760.

Jesdanun, Anick. "Delivery Delays and Other Rail-Service Problems Continue to Plague the New Owners of Conrail.” AP Press, June 15, 1999.

Martland, C.D. "Improving Railroad Productivity: Implications of U.S. Experience for Canadian Railroads.” Journal of the Transportation Research Forum 29(2), (1989): 427-433.

Martland, Carl D. "Productivity and Prices in the U.S. Rail Industry: Experience from 1965 to 1995 and Prospects for the Future.” Journal of the Transportation Research Forum 38(1), (1999): 12-25.

Machalaba, Daniel. “After Some Crippling Chaos, Union Pacific Can See the Light.” The Wall Street Journal, Page One Feature, September 7, 1999.

Morrison, Steven A. and Clifford Winston. "Regulatory Reform of U.S. Intercity Transportation." J. Gomez-Ibanez, W. Tye, and C. Winston, eds. Essays in Transportation Economics and Policy. Washington, D.C.: Brookings Institution Press (1999): 469-492.

Rennicke, William J. "Statement of William Jr. Rennicke, Vice President, Mercer Management Consulting, Inc.” Before the House Subcommittee on Railroads, Hearing on the Current State of the Railroad Industry, April 22, 1998. 
U.S. Rail Freight Industry

Rockey, Craig F. “Rail Competition and Low Rates.” Traffic World, April 16, 2001, p. 37.

Surface Transportation Board, Office of Economics, Environmental Analysis, and Administration. “Rail Rates Continue Multi-Year Decline.” February 1998 and 2000.

Surface Transportation Board. "Quarterly Rail Cost Adjustment Factor.” STB Ex Parte No. 290 (Sub-No. 5)(2006-2), March 20, 2006.

Waters, W.G. II. "Changes in Structure and Performance in the North American Rail Industry." Conference on The New Environment in Freight Rail. Queen's University, Kingston, Ontario, June 23-24, 1997.

Wilner, Frank. ““A Political Document”: Captive Shippers Pan STB Railroad Rate Study as 'SelfServing’ and not Reflective of Reality.” Traffic World, December 18/25, 2000, pp. 12 -13.

Carl D. Martland is a senior research associate in the MIT Department of Civil and Environmental Engineering, where he has been actively engaged in rail freight research since 1971. A specialist in rail transportation, Mr. Martland has studied service design, costing and control, equipment utilization, maintenance of both track and equipment, terminal operations, intermodal transportation, productivity, public policy, regulation and technology assessment. He has supervised more than three dozen research projects for the Association of American Railroads, individual railroads, and various government agencies and participated in studies of freight operations in Argentina, Bolivia, Brazil, Canada, Columbia, China, Egypt, India, Panama, Japan, Spain, and Thailand. At MIT, he has supervised more than 50 theses and worked with more than 100 research assistants, many of whom have gone on to work for the rail industry or public transportation agencies. He has submitted testimony in legal or regulatory proceedings in the United States and in Canada concerning the effects of labor agreements on productivity, the potential for modifying car hire and car service rules to improve equipment utilization, the factors affecting terminal and system performance, and the sources of productivity improvement in the rail industry since 1965.

Mr. Martland has published more than 120 papers and research reports, including papers that earned awards from the Pan American Railway Congress, the Canadian Transportation Research Forum and Transportation Research Forum. In 1991, he was a co-author of the paper that won the Transportation Research Forum's Outstanding Paper Award; in 1989, 1990, 1991, 1993 and 1994 he won the Conrail Award for the Best Paper on Railroads presented to the Transportation Research Forum. In 1997, the Transportation Research Forum selected Mr. Martland as the recipient of the Distinguished Transportation Researcher Award, citing the contributions of his research to improvements in the performance of the rail industry. 